International Journal of Linguistics, Literature and Translation

ISSN: 2617-0299 (Online); ISSN: 2708-0099 (Print)

DOI: $10.32996 / \mathrm{ijllt}$

Journal Homepage: www.al-kindipublisher.com/index.php/ijllt

\title{
The Cultural Schemas in the Meranaw Folktales: A Cultural Study
}

\author{
Farraniva S. Acmed-Ismael 8 (iD \\ Doctor of Philosophy in Language Studies, Associate Professor at Mindanao State University, Marawi City, Lanao del Sur, \\ Philippines
}

$\triangle$ Corresponding Author: Farraniva S. Acmed-Ismael, E-mail: ismael.fa85@s.msumain.edu.ph

\author{
ARTICLE INFORMATION \\ Received: May 08, 2021 \\ Accepted: June 14, 2021 \\ Volume: 4 \\ Issue: 6 \\ DOI: 10.32996/ijllt.2021.4.6.33
}

\section{KEYWORDS}

Cultural schemas,

Conceptualizations, Cultural

Linguistics, Folktales

\section{ABSTRACT}

The rich potential of folktales as a resource on matters of great cultural significance is revealed in this inquiry. In this study, the twenty (20) Meranaw stories (tutul) was scrutinized and evaluated with the critical lens focused this time on the area of cultural conceptualizations. To determine the cultural conceptualizations constructed in folktales, the analytical tool of Cultural Linguistics was used, specifically, the cultural schemas. Findings pertaining to cultural conceptualizations realized through folktales are the following: the Event schemas of courtship and marriage, honoring of the bride/wife (kapelawi/kalawi), thanksgiving (kakhandori), seasonal festivities (kalilang/kariyala), the Eid prayer (khutbah), and other social gatherings or communal celebrations (pakaradiyaan) are portrayed in the folktales; Role schemas which are not only about achieved and modified social roles or positions in a cultural group, it also includes an expected set of behavior associated with the roles. The role of a Sultan in his kingdom is depicted in the folktales; Closely related to role schemas are image schemas which provide a structure for certain conceptualizations. The latter is often readily imagined as iconic images, or popular conceptions of a person, for example, a datu is popularly imagined as a man of noble birth or a scion of the royal clan; Proposition schemas as models of thought and behavior are represented in the folktales by the order and customary law or norms of conduct (taritib ago igma). The two are the threads that establish and maintain relations in the fabric of Meranaw society. Strict adherence to taritib ago igma ensures harmony and order in society; Finally, emotion schemas contains affects and evaluations activated through association with other schemas. Presumably a very important emotion is Meranaw culture is the sense of shame or loss of face. Meranaw are a people who take pride in their lineage traced through the family tree (salsila).

\section{Introduction}

Meranaw folk literature is a rich collection of folktales, myths, legends, fables, riddles, proverbs, and more. In this vast body of oral traditions are embedded Meranaw cultural beliefs, the collective wisdom of their ancestors, and the wide range of uses served by language. Unfortunately, the bulk of this literature is still believed to be in oral form and much of it is even feared to have been forgotten already. Stakeholders - i.e. folklorists and other scholars are still in the phase of tilling the field for more "finds" or discoveries, collecting then transcribing, documenting and translating these.

The enormous problem confronting people involved in its preservation is the apathy or lack of interest of the younger generations in the oral traditions of their people. Present generations of Meranaw youth see their cultural heritage not as a legacy from their ancestors to cherish or treasure but as some foreign land they do not care to visit. The Meranaw themselves, as heritage speakers, must recognize and assume their responsibility to protect and preserve their language and their culture. This

\section{K C AL-KINDI CENTER \\ $\mathbf{R}$ D FOR RESEARCH AND DEVELOPMENT}

Your gateway to world-class research

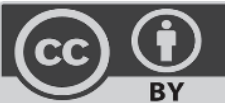

Published by Al-Kindi Center for Research and Development, London, United Kingdom. Copyright (c) the author(s). This open access article is distributed under a Creative Commons Attribution (CC-BY) 4.0 license 
gargantuan responsibility, however, becomes difficult and urgent, for the race against time has begun. Thus, there is a need to study the cultural relevance of the Meranaw story as reflected in the folktales.

Cultural Linguistics is an interdisciplinary sub-branch of linguistics that explores the relationship between language and cultural conceptualizations (Palmer, 1996; Sharifian, 2011, 2015). Conceptualizations is a cover term that refers to fundamental cognitive processes of schematization. Schematization refers to "a process that involves the systematic selection of certain aspects of a referent scene to present the whole, disregarding the remaining aspects" (Talmy, 1983). This cognitive process naturally leads to the development of schemas (e.g. Bartlett, 1932; Bobrow \& Norman, 1975; Rumelhart, 1980).

Cultural schemas are a class of culturally constructed schemas and serve as a basis for communicating and interpreting cultural meanings (Strauss \& Quinn 1997). Cultural schemas capture beliefs, norms, rules and expectations of behavior, and values relating to various aspects and components of experience (Sharifian, 2017). Cultural schemas capture encyclopaedical meaning that is culturally constructed for lexical items of human languages. Palmer (1996) maintained that it is likely that all native knowledge of language and culture belongs to cultural schemas and the living of culture and the speaking of language consist of schemas in action.

Several classifications of schemas have been proposed in Cultural Linguistics, such as schemas for cultural differences (Cook, 1994); schemas for social interaction (Nishida, 1999); and schemas for cultural-linguistic literature (Sharifian, 2011). In this study, the types of cultural schemas used for constructing the story fall under the classification of schemas proposed by Sharifian (2011), such as event schemas, role schemas, image schemas, proposition schemas, and emotion schemas. All these conceptualizations often emerge at the cultural level of cognition.

\section{Literature Review}

The same venture was done by other researchers such as Goh (1986) in her study Using Myths, Folktales and Fairy Tales in the Adult ESL Classroom. She focused on the practical, psychological, cultural, and social benefits that folktales and fairy tales offer adult learners in the ESL classroom. Her study explored the different dimensions of tales and sought to demonstrate how these narratives could be used as content materials to instruct and provide practice to ESL learners. It demonstrated how effectively tales lend themselves for use in integrative language and cultural teaching, the very same purpose that the present researcher intends to collect and analyze reading materials out of Meranaw story.

Yule (1996) points out that cultural schemata are developed in the context of a people's "basic experiences". Ketchum (2006) defines cultural schema as an extension of content schema which is culture-specific. Cultural schema or abstract schema (Oller, 1995) involves cultural familiarity which helps readers to reconstruct the text through referring to more culturally relevant scripts (Oller, 1995). This is so probably because different concepts may have different referents in different cultures and may thus generate different expectations on the reader's part. Thus, cultural schema, not dependent on the surface forms utilized in the formation of the text, involves more than a mere literal comprehension of the content of the text (Alptekin, 2006).

\section{Methodology}

This study made use of qualitative methodology of descriptive-analytical design specifically content analysis. The findings about important aspects of the Meranaw culture present in the texts which are analyzed and interpreted with Sharifian's cultural schema, the cultural linguistic analytical tool, used as critical lens. In this study, the analysis on the twenty (20) stories focused on the classification schemas proposed by Sharifian (2011), such as event schemas, role schemas, image schemas, proposition schemas, and emotion schemas.

\section{Findings and Discussion}

Schematization refers to "a process that involves the systematic selection of certain aspects of a referent scene to present the whole, disregarding the remaining aspects" (Talmy, 1983). Cultural schemas, which are culturally constructed schemas, capture beliefs, norms, rules and expectations of behavior, and values relating to various aspects and components of experience (Sharifian, 2017). Such norms, beliefs, rules, and expectations of behavior found in the stories are classified into the following: event schema, role schema, image schema, proposition schema, and emotion schema.

\subsection{Event Schemas}

Event schemas focus on patterns of behavior that should be followed for certain events (Cherry, 2019). These schemas are abstracted from people's experiences of certain events (Mandler, 1984; Schank \& Abelson, 1977). Meranaw culture abounds in social events for marking or commemorating significant occasions. It would seem that the great variety or range of social events as a feature of Meranaw society and culture is both natural to the Meranaw culture and at the same time reinforced by Islam. The Meranaw are clannish and relish huge gatherings that bring members of the clan, relations (by affinity), and associates. They put much store by number: the more relatives and relations one has, the greater the prominence and influence of the clan. In a 
way, their faith, Islam, accounts to a considerable extent for the observed propensity of the Meranaw to gatherings or social events. Islam is known to accord great importance to its expressed prime social goal - i.e. Unity and solidarity. Its social goal is realized in the faithful congregating in the masjid, especially for the Friday prayer (Juma 'áh) to pray together, all facing the Qibla. Larger events in which this mission or goal is expressed and fulfilled are the gathering for the Eid prayer and Khutbah and other Muslim festivities, and most important of all, the yearly Hajj or pilgrimage to Makkah.

In this study, the cultural conceptualizations constructed in the stories are the event schemas of Meranaw's courtship and marriage, honoring of the bride/wife (kapelawi/kalawi), thanksgiving (kakhandori), seasonal feasts/festivities (kalilang/kariyala), contest or competition (mbatalowa), and other social gatherings or communal celebrations (pakaradiyaan).

The Meranaw event schema of courtship and marriage are constructed in the stories, such as So Poteri Diyariya sa Agamaniyog (The Princess Diyariya of Agamaniyog), Tingting a Bolawan (The Golden Tingting), So Tutulan ki Poteri Kalolowan (The story of Princess Kalolowan), So Salapid ago si Radiya Ganding (Salapid and Radiya Ganding), Potri Intan Tihaya (Princess Intan Tihaya), So tutulan ki Paganay a Sebang (The Story of Paganay a Sebang) and So Tutulan ko Maitem a Ator sa Dimarao (Story of the black stone in Dimarao). These stories provide a detailed picture of the Meranaw customs and practices related to courtship and marriage.

Courtship is viewed as a process undertaken in order to win the love of someone of the opposite sex for the purpose of marriage. Meranaw courtship may start either prior to or after the marriage. There are proofs to show the existence of the latter. In the story, So Tutulan ki Poteri Kalolowan, So Salapid ago si Radiya Ganding, Si Paganay a Sebang and Si Potri Intan Tihaya, the couples did not go through the courtship period or phase before the wedding because parents usually make their selection of a partner, kin (elders), or the community. In some cases, children may be betrothed as infants, or promises (samaya) which have the weight of a covenant may be made between families regarding children still unborn. Thus, arranged marriage in Meranaw society is common because of social and economic factors that give enormous importance; that is, marriage is seen as an institution cementing a union between two families.

In the past, Meranaw courtship was carried out by parents for their sons, or daughters. The courtship initiated by them was indigenous or traditional. Foodstuffs, even perfumes, were given to the parents of the young boys or girls. Financial assistance was extended by one to the other in time of need. Service was rendered and reciprocated in some form or another (Cayongcat, 1986). According to the old folks, courtship was also done by Sultans and Datus during community affairs. Such was initiated in a unique fashion. In the story, So Salapid ago si Radiya Ganding, the Sultan held a social gathering called kalilang, and all beautiful girls from different kingdoms were invited. The ladies in the community were in attendance, attired in rich, shimmering costumes. The sons of the royal families came and occupied their seats. Then, conversations with the young ladies and courtship began. The kolintang and agong were played and the show was hilarious.

Aside from courtship in the context described above, a boy can also pay court in any appropriate gathering, as in a kanggawi'i or a vigil. For instance, in the story, So Tutulan ki Poteri Kalalowan, Saridata went to the vigil (duwali) for Poteri Kalalowan's father and he left his picture secretly with Poteri as remembrance to the girl. To some cultures, this may seem awkward or a bad omen to be courting during 'vigil' for the dead, but Meranaw before may see these events as a chance for them to have a glimpse of prospective love interests or try to make contact through the said occasion. The boy can do another form of courtship through a visit to the house of the girl where the girl's parents or other folks entertain him. In the story, So Tutulan ko Maitem a ator sa Dimarao, the beautiful lady Bai Paramisoli was courted by handsome gentlemen in their hometown. The datus courted the Bai at her house and brought some things as gifts. According to Disoma (1999), it is a belief among the Meranaw that a girl who has many suitors has great honor and prestige in the community and she is called kiyadayu'oan (having many friends and admirers).

Generally, courtship is described as a romantic affair between persons of opposite sexes, left alone together, one expressing love for the other, by word of mouth or body language, as can be seen in the streets, school campuses, and parks or in other suitable places. This description may be common in a liberated society, but in a conservative or tradition-bound society, such as the Meranaw, courtship is frowned upon as immoral, insulting or offensive to tradition laid down by ancestors. According to Cayongcat (1989), courtship prior to marriage gives importance in Meranaw society but is highly regulated. It must be done according to established norms lest it foments some rumor of indiscretion or whip up a breath of scandal and cast doubts on the lady's reputation. Violation of these norms can lead to conflict between the parties or families involved and even cause a ridu or feud in the community. As Alangca-Azis (2014) found in her study, one of the more common causes of ridu involves women's honor.

Counting among the distinctive features of the Meranaw are their elaborate, colorful marriage customs. According to Tawano (2001), marriage is something sacred in the Meranaw society. There are steps or stages to observe, as described in the study of 
Goling-Pantao (2018). It begins with kandaonga (courtship) which is undertaken through matchmakers, often in verses exchanged continually until there is an assurance on both sides about the details of the marriage. In the study of Santos (1973), cited in Abedin (2005) and Goling-Pantao (2018), there are five stages of the Meranaw marriage: kapangilay-lay; kapanuksam or kapangakap; kapaniwaka; kambitiyara; and kakhewing. The number of stages of the elaborate process could vary. Bula (1999), for example, listed in her study only four major stages: kapangilay-lay (inquiring), kapaniwaka (giving of initial gifts), kabaton sa tamok (presentation of the bride gift or dowry), and the kambitiyara (wedding ceremony). Throughout the process, there are negotiations and even katharo sa lalag or verbal fencing. It should be mentioned here that it is not always a smooth passage for the prospective groom's family. Any perceived impropriety can spoil the process and the negotiations collapse or whatever tentative agreement reached thrown overboard (peka). When the two families come to an agreement, the kakhawing (wedding proper) follows.

As the elaborate process indicates, a Meranaw woman cannot be taken as a wife without the suitor and his family going through the rituals and, above all, religiously observing the essence of sanctity. The story Si Potri' Intan Tihaya, illustrates the process that leads up to the consummation devoutly wished by the parties involved. First, the parents want to marry off their son and they do preliminary negotiations called kapangisa-isa or kapangakap, literally, knowing. This consists of go - between talks done discreetly with the parents of the girl regarding the boy's honest intentions. Thus, the next move of the parents and kin of the boy is to visit the girl's parents. During this visit, they may not mention anything about their intentions, or formally propose the marriage of their son. This procedure is called kapangilaylay (citing). In opening the proposal, the boy's parents state their intention to marry the Sultan's daughter and offer the amount of betang (dowry) they can afford. This process is called kapanoksam. Also, the family of the boy performs the kapaniwaka or gift-giving of raw food by the parents of the boy to the parents of the girl. According to Disoma (1990), traditional Meranaw who belong to a social class does the kapaniwaka as a kind of a small wedding. It is a courtship mechanism designed to win the love of the girl and the coveted favor her kin.

Pakaradiyaan (feast) is celebrated during special events and is also held during and after a Meranaw royal wedding (kakhawing). When all arrangements for the marriage have been settled, the kakhawing or wedding takes place. According to Madale (1997), this is the occasion when relatives of the bride and groom meet in the bride's residence or in a torogan for the solemnization rites of the marriage. Then after the Imam (scholar) pronounces the marriage rites completed, the wedding party for the reception and main program follows. In the story entitled So Solotan sa Darolkaya (Sultan of Darolkaya), the marriage of Radiya Sahimaredan and Poteri Malaika was celebrated in an extravagant or lavish royal wedding. It was mentioned in the stories that before and during the wedding, there was pakaradiyaan (festivity) that included chanting of bayok and playing kolintang, glamorous parade with colorful flags and arches constructed across the street, and abundant food served during the event.

On the other hand, the event schemas of the Meranaw feasts and social gatherings are portrayed in the following stories: Potri Intan Tihaya (Princess Intan Tihaya); Potri Diyaradiya sa Agamaniyog (Princess Diyaradiya of Agamaniyog); So Solotan sa Darolkaya (The Sultan of Darolkaya); Daliday a Binembar; Pakapoon o Lumbatan (Legend of Lumbatan) and So Manga Pangangayamen a Minggiginawai (The Story of Animal's friendship). These stories depict some selected traditional Meranaw feasts and social gathering, such as the pakaradiyaan (feast), kalawi (bride's short visit), kakhandori (thanksgiving), and kapamagaruwak (death rite), that further illumine the social and cultural world of the Meranaw.

In the story entitled Daliday a Binembar and So Solotan sa Darolkaya, feast (pakaradiyaan) is the most highlighted event that happened after the wedding or when the newlywed couple came to the groom's kingdom. The story Pakapoon o Lumbatan also depicts the pakaradiyaan event where the Sultan held a feast to unite the people in his kingdom. There were three days of merry-making in the stories, such as literary-musical program like chanting bayok and darangen, performing kolintang, and games like kasipa, horse race, and animal fights; and sumptuous feasting. These trappings or outward signs of the concept pakaradiyaan (feast) were a delight to Meranaw folks in times of yore. As can be gathered from the sample story, pakaradiyaan was the festive part of a wedding, or some other grand occasion like kandatu (enthronement ceremony) and the feast for unity held by the Sultan in the tale Pakapoon o Lumbatan, Pakaradiyaan as a communal festivity is an expressive way of celebrating their glorious cultural heritage-their customs and traditions - and of keeping strong and enduring their sense of community. Moreover, this traditional merrymaking is an occasion for demonstrating at its best Meranaw hospitality, especially to valued visitors. The entire community would go en fete. A festival with abundant meal often accompanied by a ceremony, games, various forms of entertainment, and kalilang (literary-musical program) was an exciting and social event among Meranaw in the past.

Among the Meranaw social gatherings, kakhandori (thanks giving) is a common event. It means "feast of thanksgiving" in honor of loved ones or special people of great stature. Traditionally, the Meranaw people hold kakhandori to give thanks for the daily blessings and guidance received from Almighty Allah, or to celebrate significant achievements, such as giving birth, enthronement/coronation ceremony of traditional leaders (with gerar), graduation or passing a licensure examination, 
appointment to a high position, and other successes of members of the family. Kakhandori is expensive as giving cash (sadagah) and serving abundant food are due to regular practices. The food may be brought to the mosque (masjid), to the torogan, or the house of the family sponsoring the kandori. It is intended for religious people, family members and friends. The story Poteri Diyaradiya sa Agamaniyog gives a concrete illustration of the concept of kakhandori : when the Sultan held a simple thanksgiving at home because he had a good dream that he would be blessed with a child soon. The Sultan invited the religious people and offered them abundant food and money. Also, in the story So Manga Pangangayamen a Minggiginawai, the Datu held an extravagant kandori in celebration of his child's birthday. Plenty of food was served and the kalilang played. Nowadays, these social gatherings called kakhandori are still a popular Meranaw practice held in function halls and establishments like restaurant and hotels.

Another Meranaw social gathering reflected in the story is kapamagaruwak (death rite). In the story of Tutulan ki Solampid (The story of Solampid), the death rite for Sultan sa Agamaniyog was performed. During the hundredth day of the Sultan's death (gatosan), the family prepared food to serve the arowak (souls) by offering it to other people and asking the tuan (religious Datu/olama) to partake of it and perform some prayer rituals. This practice, which persisted among traditional Meranaw before, is no longer as faithfully observed since it has been realized to be un-Islamic. However, as mentioned in a previous discussion, abandonment of such practices as the kapamagaruwak cannot be claimed to be absolute, as tradition-bound Meranaw families in remote communities obdurately cling to the practice (inandang or andang a meona). This results in a melding of an old or traditional custom and Islamic practice. Such melding or syncretism is observed in other aspects of the modern Meranaw way of life like weddings where the East and the West meet, or Meranaw tradition and Islamic practice are fused, as pointed up in Abedin's thesis (2005).

Lastly, the concept of honoring the bride/wife (kalawi) among Meranaw people is portrayed in Potri Intan Tihaya (Princess Intan Tihaya). The event schema of kalawi is still a practice of Meranaw families current in some rural areas in Lanao. Kalawi means the parents-in-laws' invitation to a son's wife to visit or live in their home, with certain requirements. According to Dr. Dalomabi L. Bula, a Meranaw linguist, kalawi is done under the taritib ago igma (traditional-indigenous law), that a wife is not allowed to visit her husband's place if he hails from another place unless the kalawi is performed. Kalawi is another traditional practice that measures kinship tie. It is not an easy task. It is usually regarded as the second stage of a marriage ceremony as it entails much monetary expense, time, and physical effort from the parents and even relatives of the husband whose wife is to be invited to come to his place for the first time.

Historically, the traditional homeland of the Meranaw includes the Lanao provinces which are divided into four principalities known as the pat a pengampong ko Ranao, namely, Unayan, Masiu, Bayabao, and Baloi (Disoma, 1999). In many cases, the bride and groom's families are from different principalities; hence, the kalawi practice is required as shown in Potri Intan Tihaya. The frenetic three - day preparation and feast are described. There was preparation for a banquet and a carabao was slaughtered to give more honor to the visiting wife. Certain games like kasipa sa manggis (kickball with tag prizes) and presentations like kalilang (playing musical instruments) and laila (fireworks) were held. According to Dr. Alawi, during her fieldwork in Saguiaran for a Cultural Heritage Center research project, she was able to interview elderly locals who gave interesting accounts of certain practices related to kalawi, specifically a palanquin-like decorated royal chair (tangkongan) for the bride/wife on which she was borne all the way to the husband's home and the washing of her feet by a member or oripen/tagikor of the husband's family before she would set foot on the threshold of the latter's home. For the symbolic washing of the feet, a porcelain vessel or vase for holding water - valued as a piece of heirloom - was used. The porcelain vessel described as giving off different colors was in the possession of the family's eldest daughter. These are not mere trappings; the gestures that make up the ritual are symbolic. For example, the use of a conveyance or tangkongan connotes honor, respect or recognition of the bride's social status, and by extension, her family/clan. Washing off her feet means a promise or pledge to treat her as a cherished member of the family. In Meranaw society, the new groom (miyakamong) holds an honored or pride of place in her new family (seselaen).

Event schemas usually encompass subschemas of events within events (Farzad, 2011). As revealed in this study, event schema of Meranaw's courtship and marriage, feasts and social gatherings, such as, wedding (kakewing), honoring of the bride/wife (kapelawii/kalawi), thanksgiving (kakhandori), death rite (kapamagaruwak), and feast (kapakaradiyaan) usually include subschemas of joyful social activities like seasonal festivities (kalilang/kariyala), chanting of bayok (kambayoka), contest or competition (mbatalowa), which are held for a number of days, for example, an entire week. Moreover, Meranaw events are characterized by colorful decorations and an abundance of food. Meranaw families take pride in their material possessions and flaunt these on such occasions. Failing to measure up to expectations spells embarrassment (kapakaito) or diminishment of the family's prestige and stature. Sharing and serving food is a way of showing kindness and generosity among Meranaw. Also, folks agreed that Meranaw events are an avenue for family bonding and unification or solidarity. 
Therefore, the Meranaw event schemas connote close family ties, solidarity, hospitality, generosity, and penchant for, or natural inclination to, merriment. As stated earlier, they put a premium on numbers. Gatherings are an occasion for showing how extensive one's clan is. This is used to take the measure or worth of a person in Meranaw society.

\subsection{Role Schemas}

Role schemas are schemas that include knowledge about achieved and ascribed social roles and the expected behavior associated with these roles (Nishida, 1999). Augoustinos and Walker (1995) define role schemas as "knowledge structure that people have of specific role positions in the cultural group". In this study, the role of the Solotan (Sultan) and Bai-i-Labi (honored woman) in the twenty stories are exposited below.

In Meranaw culture, men occupy high-ranking positions in the agama as sultan, datu, kali, wakil and imam. Generally, they have the upper hand in political deliberations and decision-making processes (Nolasco, 2004). The role of the Sultan in his kingdom is portrayed in the following selected stories: So Tutulan ko da Kapatay o Solotan sa Agamaniyog (Story before the Death of Sultan Agamniyog), So Solotan sa Maganding (Sultan Maganding), and Solotan sa Darolkaya (Sultan of Darolkaya). The Solotan sa Agamaniyog's kingdom is an exemplar of a good sultan/ruler as attested to by the peaceful life enjoyed by his subjects. The setting is evocative of the ideal world limned in pastorals, a never, never land. This idyllic condition reflects on the ruler's wise governance. The Sultan is the equivalent of a king, an emperor, a dictator, or local president. He exercises executive, judicial, and legislative functions, his decisions informed or guided by the taritib ago igma (customary law). For instance, Solotan sa Darolkaya promulgate

$\mathrm{s}$ the ordinances and tries to resolve the ridu (feud) in his kingdom.

In stark contrast is that instance when Solotan sa Maganding's son was kidnapped by one of his slaves; the Solotan felt so disappointed that he lost interest in his role and began behaving like a despot or dictator for quite some time. He issued harsh edicts like proscription or ban on festivals and merriment of any kind. Laws that once guided life in the kingdom and were beneficial to the people, assuring them of an orderly and progressive society, were no longer passed. Despite the fact that the sultan had been remiss or negligent in ruling his kingdom, no one among his subjects dared to criticize him or his administration because he was revered and a symbol of authority to them. According to Cayongcat (1986), the true sultan of a place may yet owe the grace and glamour of his title to a more powerful sultan who exercises a more comprehensive authority over a district.

Among the Meranaw, the sultan is the leader of isa ka agama (one community). Each agama has one sultan. "He is the chief judge and the chief executive of his state" (Buat, 1977). He settles disputes, promotes peace and order, aids the needy members, performs traditional rites, assists entities and religious affairs, attends social and religious gatherings, provides financial assistance for the construction of mosques (Benitez, 1968), and determines the successful use of practices or salsila (genealogy), taritib ago igma (Madale, 1976). Ably dispensing above cited functions, the Meranaw Sultan is given one of the following titles (Madale, 1976): panondiongan (most high), kasangoan (adviser), paniyambaaan (great), ampuan (most revered), ampatua (wise), solotan a pitilan/pitulan (chosen sultan), simbaan (idol), solotan a dalomangcob (wise sultan), sangcopan (unbeatable), solotan a adil (wealthy sultan), pangarongan (adviser), and solotan a gaos (moneyed sultan). These are ranked titles in Meranaw society (Arinto, 1996).

Over time, the Meranaw Bai $i$ labi or woman has positions/roles in the formation of Meranaw society in spite of the inequality between them and their male counterparts. The role of Bai or woman is delineated in the stories Tingting a Bolawan, So Tutulan ki Daliday a Binembar, Si Poteri Kalalowan, So Tutulan ki Solampid, etc. First and foremost, it is the home where women play the primary role of a daughter, a mother, an aunt, and a doting grandmother. They are not merely pacifiers or wives; they also exercise an authority/power in their society. When a Meranaw woman or Bai is an adult, the menfolk consult her on important family and community affairs matters, more so if she holds a traditional title (gerar) and is known for her wisdom. When getting married as a bachelor lady, she is entitled to costly bridal gifts and nuptial ceremonies commensurate with her family's social status. Aside from being the mistress of the home, such Meranaw women may assume varied titles and statuses in the traditional sultanate. For example, in the dissertation of Alangca-Azis (2014), a Meranaw woman of some stature in the community may be tapped for a critical role, that is, as a mediator or negotiator in conflict resolution. As revealed in the same source, in many cases, a woman has proved to be more appealing and effective in that role. She has shown ingenuity and enviable cunning. A woman always occupies a special dignified or privileged position at all social functions.

Bai sa Agamaniyog, for instance, in the story, So tutulan ko da Kapatay o Solotan sa Agamaniyog, holds the title (gerar), "Bai", the female counterpart of "Sultan". Bai lives in the torogan (royal house), the symbol of rank, status, authority and power among the Meranaw and she is the highest-ranked among women in the community. Meranaw women assume varied titles and statuses in the traditional sultanate. The title of the 'Bai-a-Labi' is the feminine equivalent of the title Sultan or Datu and she is expected to uphold the honor and the prestige of the community and to perform her functions as stated in their customary laws.

Page | 285 
In Meranaw society, even if a woman does not hold any title but is already an adult known for her wisdom, she would be looked up to by the people, with the menfolk seeking her advice or consulting with her regarding important family and community affairs. This is seen in the story So Iringa ko Babay a Bidowin (Story of Lady Bidowin). Babay a Bidowin is portrayed as an independent woman, a poor widow with no fortune and managed to serve only rice porridge to her children for their daily "meal" or subsistence. One day, she had an accident and the business merchant gives all her products to Babay a Bidowin. This unexpected bounty allowed her to live like royalty despite her not having a royal title. Moreover, her sacrifices and hard work for raising her family had paid off. Nishida (1999) maintains that these schemas include "knowledge about social roles which denote sets of behaviors that are expected of people in particular social positions". Such schemas include knowledge about different characteristics associated with each role, such as clothing, age, way of speaking, plans, etc.

Therefore, the Meranaw role schemas have their own socio-political structure: the Sultanate system; this is a socio-political order that is complete in itself and gives assurance of an orderly society. The members of the Sultan's family belong to the highest level of society (pegawidan). The findings revealed that the Sultan rules over his sultanate independently. It is recognized that in traditional Meranaw society, the Sultan is the chief authority to whom every one deferred and owed fealty or loyalty. Even in Meranaw Islamic belief, the head of the family is the man or Sultan.

In the study of Rogong-Rasul (2015) on the role of traditional leaders, a greater variety of roles and functions were mentioned by her key informants who are traditional leaders themselves - e.g. presiding over meetings or kapmosawir, attending weddings (his arrival serving as the "green light" for the rites to begin), and maintaining diplomatic ties or harmonious relations with other Sultans. Moreover, the associated role schemas often involve knowledge about obligations and responsibilities (Farzad, 2011). Among the Meranaw, the role of the Sultan is vested with authority for settling disputes, maintaining peace and order, aiding his needy followers, constructing mosques, and attending social-religious gatherings. As a sign of his subjects' respect and deference, the Sultan receives adat during weddings and the head of the slaughtered carabao is delivered to his torogan or home. Hence, the Meranaw consciousness of role schemas reveals a patriarchal society, with the male as head or leader.

\subsection{Image Schemas}

In a Meranaw community, a wealthy individual who is of royal blood is called "datu". However, if he is not of royal blood, but only the rich and influential, he can also be called "datu". In the story entitled So Ibrahim, for instance, the datu is portrayed as an influential leader. The scenario below described in the stories analyzed appears to instantiate the Meranaw conceptualizations of Sultan.

Ibrahim is not a Sultan, but is only a wazir or legal consultant of Sultan. One day, when he was sick, he called all his friends and the merchants in the land of Babil. The people came to his place and give respect to Datu Ibrahim because he was known as a wealthy merchant with many torogan (heritage house) and kapal (boat).

Moreover, this is not all that the word "datu" implies. The usage of the terminology is broad. One can be called "datu" because of his royal upbringing, graceful bearing, pleasing appearance and exemplary conduct. If his royal title is unknown, he can be addressed as "datu". In the story, for instance, Si Miskin is depicted as the image of an ordinary datu. Consider the following scenario portrayed in the story.

Miskin is the only son of Sultan and Bae Agamaniyog. He was called Miskin which literally means poor. Because of his being generous, he gave all his wealth to his people until he became poor. He then went to another kingdom to start a new life. Unfortunately, he was imprisoned and accused as murderer and thief. But because of his good heart and wisdom, he saved the life of the princess and they got married. Despite Miskin becoming poor, he still carries his image as datu because of his exemplary conduct in helping other people and his royal upbringing.

The term "datu" is a popular usage. But it is not fully understood. In places outside Lanao, datu is confused with the word "sultan", who is of noble birth and scion of a royal clan. The Sultan can be called "datu", but the datu may not be called "sultan", if he had not been crowned before as sultan. The two titles are not interchangeable. However, ideally, the sultan is a datu himself, wisest and richest Meranaw, and comes from a royal class of Meranaw society whose descent can be traced from the first sultan (Buat, 1977).

Image schemas are those which provide structure for certain conceptualizations [between mental images and abstract propositions] that are readily imagined, perhaps as iconic images, and clearly related to physical (embodied) or social experiences". This schema is a popular conception of a person or object that strongly resembles another. The word image means 
a visual representation or mental picture or impression of something. The term "datu" is a popular honorific reserved for titlebearing personages - e.g. Sultan, Radiamoda, Cabugatan, etc. However, it is not fully understood. As already explained, in places outside Lanao, Datu is confused with the word "Sultan", who is of noble birth and scion of a royal clan, and can also be addressed as "Datu"; on the other hand, the Datu may not be called "Sultan", if he had not been crowned before as sultan. The image schemas of Datu and Sultan are described in the following stories: So kiyasaelin o Radiya Ismayatin (The Changed Radiya Ismayatin), Si Miskin (The Poor) and So Ibrahim (Ibrahim story).

Hence, the image schema of "datu" uncovers a customary manifestation of respect. Among the Meranaw, an influential sultan carries the name of his region or rule immediately after his rank; although his title is known, he may just be called "datu". In a gathering, in the street, or in a vehicle, a person with a good reputation is addressed as "datu". Briefly, "datu" is an attribute and an honorary title among Meranaw. According to Meranaw folks, the image of "datu" is a man of prestige and good standing in the community. A man designated by the form address "datu" does not necessarily carry a gerar. It is clear that the term "datu" implies respect and connotes social rank and admirable qualities.

\subsection{Proposition Schemas}

The Meranaw propositional schemas revealed in this study break the taritib ago igma (customary laws) and, consequently, harm everyone. In Meranaw culture, the proposition schemas of breaking the taritib ago igma by indulgence or indiscretion may be represented by illicit love which is most offensive and thus prohibited in the Meranaw customary law and entering the house when the housewife or daughter is alone. These schemas are portrayed in the story entitled Si Potri Maalika (Princess Maalika). A summary of this scene is given below.

Potri Maalika, is the only daughter of Datu and Bae sa Agamaniyog. After her birth, Bae sa Agamaniyog passed away and the Datu decided to sail away to find gold to provide for her dear daughter, as promised. Potri Maalika's father ordered her to stay away from anyone even from her uncles and not to let anyone enter her room while he is away from her. The Datu sa Agamaniyog's last statement to her daughter was, "Be careful that our social worth is not dirtied.". But Potri Maalika's wicked uncles then accuse her of indulging in an illicit love making when they cannot have their way with her. They send a letter to her father and accuse Potri Maalika of doing malicious acts. Immediately her father punished her daughter to death without even hearing her side.

The story above shows the proportion schemas of breaking the Meranaw customary laws in the form of compromising an unmarried woman's reputation by casting doubts on her chastity and entering the house with no permission. The punishment for willfully transgressing against tradition by indulgence in illicit lovemaking is death or exile. According to Meranaw folks, the igma restricts the relation of a man to a woman. For instance, should it happen that one has ruined a woman's reputation by molesting her or having furtive sex with her and the latter complains, igma has a role in the disposition of the case. Literally, igma which means customary law and suggests consensus usually accompanies the other term taritib. Together the two terms make clear that crucial or important decisions made requiring consensus or general agreement. For example, succession-related matters are deliberated on by the Council of Elders (pelokelokesen in Meranaw). In the example cited, igma dictates that the man must be prevailed upon to make an honest woman of the latter by marrying her if the woman is single. If the man is unwilling to remedy the situation through marriage, a 'denial' or 'kasalaan', a fine, must be given by the man. The fine is in the form of property or money. The offender is liable or obligated to salvage the disgrace incurred by the aggrieved party. Moreover, one belief of the Meranaw that falls under igma is one must not enter a house if the housewife or daughter is alone. Before going up a house, one must, in a courteous manner, find a way to give the people upstairs the idea that someone outside is coming up (Cayongcat, 1986).

Proposition-schemas may be defined as abstractions that act as models of thought and behavior (Quinn, 1987). These schemas specify "concepts and the relations which hold among them" (Quinn \& Holland, 1987). The threads that establish and maintain relations in the fabric of Meranaw society are the taritib ago igma (customary law). Taritib is the Meranaw term for the ancient or traditional order/ code or law defining the relationships among the communities and their members (Saber, 1975). It consists of time-honored precedents dating back to remote or unrecorded times and has remained inviolable over time; this serves as a resource - a veritable Charter-to which later decisions are referred to or based. (Isidro, 1967; Mednick,1965). From the Meranaw point of view, taritib means order, protocol, or charter. It governs the relationship of people and the legitimate succession of, and claim to power, status, and rank; it defines the relationship between people and communities. It also defines the relationship between or among the communities and between communities and the Pengampong. In general, it defines, binds and governs the entire socio-political organization and territorial division of Lanao. 
Therefore, the proposition schemas of the Meranaw are well-defined. The Meranaw have an established social order and usages; the igma is a body of usages or norms of conduct which are generally accepted in a Meranaw society. It lays down specific cultural norms that guide one's practices, what one should do, how one should act, and what one should say in a particular situation. These are the shared expectations and rules that guide behavior of people within a social group and make sense of each other's actions.

\subsection{Emotion Schemas}

The emotion schemas constructed in the stories are the Meranaw maratabat (pride) and kayaan (shame). Thus, maratabat (pride) and kayaan (shame) are the dominant cultural traits of the Meranaw. These are activated through their association with other schemas such as kinship. The emotion schemas of maratabat and kayaan are aspects of cultural values that make Meranaw different from other ethnic groups in Southern Mindanao.

Accordingly, "maratabat" is a Muslim Meranaw term which means honor or pride. According to Cimene et al. (2019), it is the wellspring of family values and their aspiration to improve the economic status to the point of endangering the lives of the family members. This emotion schema of maratabat is portrayed in the story entitled So Solotan sa Darolkaya. Some scenes in the story that dramatize pride among Meranaw are summarized below.

At the end of the story, Radiya Sahimaredan fought with his enemies and when his separated first wife heard the news, she told their son to rescue his father against his enemies. Even though the son does not know his father because he left them for a long time, still he chose to travel to the other kingdom and helped his father fight against his enemies.

In this study, maratabat is revealed to be the driving force that motivates the Meranaw to protect every member of his or her clan and preserve family honor. This "bounden duty", a matter of principle and pride, can be partly explained by Meranaw society being collectivists. One must always place group interest above personal need or interest. A Meranaw local term denotes this stance: tindeg, literally noble or principled position taken in a critical situation. The Meranaw have a deep sense of personal honor, dignity, self-esteem, and reputation called maratabat (Cimene et.al., 2019). Maranda (2009) contended that maratabat is more than the amor propio (self-esteem) of the Filipinos. It is one of the distinguishing features of the Meranaw culture-a mark of distinction which makes them unique among all other ethnic groups. To the Meranaw, maratabat is worth dying for. Closely related to maratabat is the high valuation given by the Meranaw to a sense of shame. This is portrayed in the stories of $S i$ Paganay a Sebang and So Solotan sa Maganding. A summary of these stories is presented below.

In the story, Si Aya Paganay a Sebang, the only daughter of Datu and Bai Romaging, was accidentally made pregnant because the Datu' Linding a Bimban secretly attempted to put an 'katao' or love charm to Paganay a Sebang's water jug. The Datu and Bai could not believe what happened to their daughter; they felt sad and ashamed because they knew that nobody abused her. Then, they decided to keep her away and hidden in the forest so that nobody would know about her condition, which was a disgrace to the family.

On the other hand, the story entitled So Solotan sa Maganding portrayed the emotion of shame, when llalabaw asked persons the way to her aunt's place to go home with her step-sisters and her aunt insulted her, telling her that she should go alone because her mother is a bisaya (slave). Finding her aunt's treatment of her unbearable, Ilalabaw collapsed. Later, she left the kingdom and went to the hometown of her mother to trace her lineage and track down her relatives.

Meranaw people usually associate the feeling of 'shame' with certain situations. The closest synonym for it in other cultures is loss of face. 'Shame' in this context does not necessarily involve guilt but discomfiture, disgrace or dishonor. One basic characteristic of the Meranaw is the premium they place on kinship and family honor. The bangesa (bloodline) of a family is given importance because it connotes royalty, unity or solidarity and consolidation of forces or strength. In the story Si Aya Paganay a Sebang, the Solotan and Bai decided to keep their daughter, Aya a Paganay a Sebang, in the forest because of her mysterious pregnancy. They must find a way to keep the scandalous matter of public knowledge as the dishonor disgraces the entire clan; her pregnancy out of wedlock is a mortal blow to the clan's maratabat or pride. The daughter was thus cast out or disowned by her family to protect the honour or dignity of their lineage.

On the other hand, in the story So Solotan sa Maganding, llalabaw tried to trace her family and lineage to relieve her feeling of shame. When she found out that she was of royal descent, the son of Solotan Maganding married her. The Meranaw trace their lineage to common ancestors. Their folk narrative, Radia Indarapatra, and the epic Darangen are treasured as historical accounts of the lives of their semi-divine ancestors. The salsila (genealogy) is a written document that authorities and knowledgeable old 
folks may orally narrate. It bespeaks a common ancestor and records relationships either by descent or marriage (Tawano, 1989). Tracing one's lineage comes in handy in settling ridu. Having a common ancestry is usually a deciding factor. The salsila is customarily recited at the dialaga or even the kakakewing by both sides. It is also a requirement for claiming one's right to a gerar or traditional title. Being able to trace one's descent to a noble origin grants legitimacy to such right.

Dr. Labi Riwaring, Chairwoman of the Folklore Division of MSU-Mamitua Saber Research Center, concludes that the essence of Meranaw story does not lie only in its entertainment value; stories are also vehicles of moral lessons. She adds: "It is one way of educating the children to be wise and respectful". Similarly, Dorson (1972) and Thompson say that folktales are intended to fulfill the entertainment and serve the purpose of educating young people as to a people's culture (beliefs, customs, ways of doing things, and what is considered to be entertainment good or bad, etc.). Therefore, the Meranaw story is a repository of a people's collective wisdom and a form of entertainment. Dundes (1965) views folklore like folk tales and fairy tales as "units of worldview". Bettelheim (1977) believes in the higher purpose of fairy tales (this should include folk tales), which is to sow in the minds of young readers enduring lessons through "enchantment". This is actually a restatement of the Horatian principle that a literary work must delight to teach or instruct, which is what folktales do.

Emotion schema contains information about effects and evaluation. Lutz (1987) observes that emotion concepts may be instantiations of certain schemas. These schemas are, in fact activated through their association with other schemas (Nishida, 1999). Palmer (1996) maintains that "emotions are complex configurations of goal-driven imagery that govern feeling states and scenarios, including discourse scenarios". Lutz views emotions as social and cognitive in nature that observes, defines, explains and understands emotions primarily by reference to the events or situations in which they occur" (1987).

Yule (1996) points out that cultural schemata are developed in the context of a people's "basic experiences". Ketchum (2006) defines cultural schema as an extension of content schema which is culture-specific. Cultural schema or abstract schema (Oller, 1995) involves cultural familiarity which helps readers to reconstruct the text through referring to more culturally relevant scripts (Oller, 1995). This is so probably because different concepts may have different referents in different cultures and may thus generate different expectations on the reader's part. Thus, cultural schema, not dependent on the surface forms utilized in the formation of the text, involves more than a mere literal comprehension of the content of the text (Alptekin, 2006).

Conceptualizations like schemas have an individual basis as well as an emergent basis at the cultural level of cognition. Cultural conceptualizations are often instantiated in various cultural artifacts and activities. In this perspective, language is viewed as a distributed system as well as a repository for cultural conceptualizations. Various aspects of human languages may encode conceptualizations that reflect the cultural experiences of their speakers (Sharifian, 2011). Thus, language always carries meanings that represent the culture of a particular social group. Language use is culturally determined or subject to the norms, values, and ideals of the culture represented by the speakers. Politeness formulae and pronominal use are illustrative of this. Therefore, language is a part of the culture, and through it expresses cultural beliefs and values, and that the specific usages of a given the word are peculiar to a language and its relationship with culture (Guessabi, 2011).

\section{Conclusions and Recommendation}

Like other Meranaw folk narratives, stories are repositories of the collective wisdom of the forebears of the Meranaw gained from their struggles and other experiences to build an orderly, progressive society in their own time. In these tales are enshrined principles and beliefs, values and cherished traditions left as a legacy by ancestors. This precious legacy constitutes threads that Meranaw people contributes to the tapestry of world history and heritage.

Conceptualizations like schemas have an individual basis as well as an emergent basis at the cultural level of cognition. Cultural conceptualizations are often instantiated in various cultural artefacts and activities. In this perspective, language is viewed as a distributed system as well as a repository for cultural conceptualizations. Various aspects of human languages may encode conceptualizations that reflect the cultural experiences of their speakers (Sharifian, 2011). Thus, language always carries meanings that represent the culture of a particular social group. Language use is culturally determined or subject to the norms, values, and ideals of the culture represented by the speakers. Politeness formula and pronominal use are illustrative of this. Therefore, language is a part of the culture, and through it expresses cultural beliefs and values, and the specific usages of a given the word are peculiar to a language and its relationship with culture (Guessabi, 2011).

Teachers of other subject areas like Social Studies must be actively involved in maintaining the vitality and vibrancy of Meranaw culture. They should be encouraged to develop and adopt the cross-cultural perspective that enables them to compare different cultures and impress upon students that the peoples of diverse cultural backgrounds have much to share because they are different. Every opportunity that presents itself must be seized to ransack the local culture for illustrations of such ideal or standard as kambilangataw, for example, and cultural values like maratabat (pride or honor) and kapamagawida (mutuality or

Page | 289 
reciprocity) and compare these with similar ideals and values of other cultures. This is one strategy for helping the younger generations reconnect with their cultural roots and develop pride in their rich cultural heritage. Other teachers should also sign up for the cause of multicultural education that celebrates diversity and the preservation of local cultures like Meranaw culture.

Cultivation and preservation of ethnolinguistic individuality and vitality is a collective effort driven by recognising that it is only the uniqueness or distinctiveness of a culture that can render the constituent parts creative, contributing, self-respecting and other-accepting of a supra-national design.

\section{References}

[1] Barrett, F.C. (1932). Remembering. Cambridge, UK: Cambridge University Press.

[2] Cook, G. (1994). Discourse and literature. Oxford: Oxford University Press.

[3] Dehghan, F. et.al (2011). On the cultural schema and Iranian EFL learners' reading performance:A case of local and global items. Journal of Pan-Pacific Association of Applied

[4] Disoma, E. (1999). The Meranao: A study of their practices and beliefs. Ivory Printing and Publishing House, Iligan City.

[5] Dorson, R. (1972). Folklore and folklife: An Introduction. University of Chicago press.

[6] Dundes, A. (1965). The study of folklore. Prentice-Hall Publication. Indiana University.

[7] Goh, L. (1986). Using myth, folktales and fairy tales in the adult ESL classroom. Thesis. University of British Columbia.

[8] Goling, A. (2018). The language of bangsa as Meranaw ideology in kakawing speeches: A critical discourse analysis. Dissertation. Mindanao State University-lligan Institute of Technology.

[9] Guessabi, F. (2011). Blurring the Line between language and culture. Improving literacy and communication language magazine.

[10] Lutz, C. (1985). The Anthropology of emotions. https://www.jstor.org

[11] Madale, A. (1997). The Maranaws: Dwellers of the lake. Rex Printing, Company Inc. Quezon City.

[12] Nishida, H. (1999). A cognitive approach to intercultural communication based on schema theory. International Journal of Intercultural Relations.

[13] Nolasco, L. (2004). The traditional Maranaw governance system: Descriptives, issues and imperatives for Philippines public administration. National College of Public Administration and Governance, University of the Philippines Diliman.

[14] Palmer, G.B. (1996). Towards a theory of cultural linguistics. Austin.: University of Texas Press.

[15] Saber, M. (1975). Maranao. Solidaridad Publishing House. Manila.

[16] Sharifian, F. (2017). Cultural linguistics: Cultural conceptualisations and language. John Publishing Company. Amsterdam, Philadelphia

[17] Sharifian, F. (2015). Language and culture. The Routledge handbook of language and culture.

[18] Sharifian, F. (2011). Cultural conceptualisations and language: Theoretical framework and applications. Amsterdam: John Benjamins Publishing.

[19] Strauss, C. \& Quinn, N. (1997). A cognitive theory of cultural meaning. Cambridge, UK: Cambridge University Press.

[20] Talmy, L. ((1983). How language Structures Space. Springer, Boston, MA

[21] Tiburon, A. (2017). Thotholan: Mga alamat at pabulang Meranaw. Rex Printing, Company, Inc. Quezon City. Philippines

[22] Quinn, N. (1987). Convergent evidence for a model of American marriage. In D. Holland \& Quinn (Eds). Cultural models in language and thought. Cambridge, UK: Cambridge University Press. 